\title{
Evidence of multi-functional peptide activity: potential role of KT2 and RT2 for anti-inflammatory, anti-oxidative stress, and anti-apoptosis properties
}

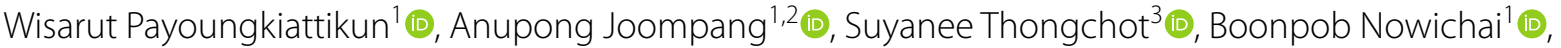 \\ Nisachon Jangpromma $a^{1,4}\left(\right.$ and Sompong Klaynongsruang ${ }^{1,2^{*}}$ (D)
}

\begin{abstract}
Although several explications of anti-inflammatory therapeutic substances for treating inflammatory-related diseases have been broadly discussed within the last few decades, peptide-based compounds display the potential to be novel inflammation treatment agents. Here, we evaluated the anti-inflammatory activity and other inflammationassociated activities, including anti-oxidative stress and anti-apoptosis properties, of the cationic peptides KT2 and RT2. Nitric oxide (NO) and other inflammatory markers were evaluated in lipopolysaccharide (LPS)-stimulated RAW 264.7 cells co-incubated with peptides. The levels of interrelated gene and protein expressions were quantified. Peptides formed complexes with LPS and displayed anti-inflammatory properties by reducing NO and pro-inflammatory cytokine production in inflamed RAW 264.7 cells. These peptides also exhibit a strong suppressive effect on mRNA expression levels of inducible nitric oxide synthase, tumor necrosis factor-a, signal transducer and activator of transcription 1, c-Jun N-terminal protein kinase (JNK)-1, nuclear factor kappa B (NF-KB), and p38 mitogen-activated protein kinase (MAPK), which affects the decay of phosphorylated JNK-1, p38 MAPK, and NF-KB p65 protein expression. Both peptides induce up-regulation of anti-inflammatory mRNA and protein expression levels of extracellular signal-regulated kinase and mRNA expression levels of MAPK phosphatase-1. Also, the production of reactive oxygen species was observed to be markedly reduced. Furthermore, peptides exhibited an anti-apoptotic property. To our knowledge, this is the first report of the multi-functional peptides KT2 and RT2 exerting broad biological activity related to anti-inflammatory effects. These peptides have potential for delivering a medical method for the handling of inflammation-related diseases.
\end{abstract}

Keywords: Multi-functional peptides, MAPK pathway, Leucrocin I, Cytokine expression, Peptide treatment

\section{Introduction}

Bacterial infections are one of the main reasons for acute and chronic inflammation. In light of this knowledge, the endotoxin lipopolysaccharide (LPS), a constituent of Gram-negative bacterial outer membranes, acts as a key

\footnotetext{
${ }^{*}$ Correspondence: somkly@kku.ac.th

2 Department of Biochemistry, Faculty of Science, Khon Kaen University, Khon Kaen 40002, Thailand

Full list of author information is available at the end of the article
}

positive stimulator of macrophages, a type of inflammatory-response immune cell, resulting the activation of Toll-like receptor 4 signaling cascading through a protein adaptor, the LPS-binding protein [1]. The resulting inflammatory process leads to up-regulated of production of pro-inflammatory cytokines and inflammatory signaling molecules on immune cells $[2,3]$ via pathway activation for nuclear factor-kappa $B(\mathrm{NF}-\mathrm{kB})$ and activator protein-1 (AP-1) [4]. Uncontrolled inflammation can 
promote the progress of various diseases and organ disorders [5-9].

Moreover, a connection between inflammation and oxidative stress has been proved. Immoderate reactive oxygen species (ROS) generation is the key marker of oxidative stress occurrence. Verification indicates that this molecule is presented in various chronic inflammatory diseases [10]. Furthermore, the reactive species can react with the ring structure of guanine in DNA, yielding chemical modification of the bases, together with a breakdown of the DNA strand, which leads to cell apoptosis [11]. In parallel, excessive oxidative stress and inflammation are documented to be involved in carcinogenesis disorders, leading to the formation of cancers [12]. Hence, the inhibition of the inflammation process might be an effective way to reduce cell damage from oxidative stress, the apoptosis process, and cancer development as well (Additional file 1: Fig. S1).

Recent investigation proved that cationic antimicrobial peptides exhibit an anti-inflammatory property and suppress the inflammation initiated by bacteria [13]. Nevertheless, very few pieces of evidence have demonstrated a peptide associated with other inflammation-related activities and broad biological activities. Previously, KT2 and RT2, modified cationic Leucrocin I peptides, have been shown to exhibit broad antimicrobial activity [14, 15]. Furthermore, these peptides possess anti-cancer properties $[16,17]$. However, their anti-inflammatory and other related properties are completely unknown. Thus, this research targeted their inflammatory prevention behavior and related mechanisms induced by these cationic peptides. The collective results reveal that KT2 and RT2 can act as truly multi-functional peptides, and that they possess antimicrobial, anti-inflammation, anti-oxidative stress, anti-apoptosis, and anti-cancer activities. The features discovered in this study may make KT2 and RT2 appealing for use as candidates for treating bacterial infection and other inflammation-associated diseases.

\section{Materials and methods Reagents and peptides}

Antibiotic/antimycotic (penicillin/streptomycin/amphotericin B), fetal bovine serum, RPMI 1640 medium and trypsin-EDTA were obtained from Gibco (MA, USA). 3-(4,5-Diamethylthiazol-2-yl)-2,5-diphenyltetrazolium bromide (MTT) was received from Eugene (OR, USA). Dimethyl sulfoxide and LPS from Escherichia coli O111: B4 were provided from Sigma-Aldrich (Steinheim, Germany). TRIzol ${ }^{\circledR}$ reagent was received from Thermo Fisher Scientific (MA, USA). KT2 and RT2 peptides were obtained from Anunthawan et al. [14]. Other reagents were purchased at the highest quality available.

\section{Cell culture}

A murine macrophage cell line (RAW 264.7) was obtained from the American Type Culture Collection (VA, USA). It was seeded in RPMI 1640 complete medium containing $100 \mu \mathrm{g} / \mathrm{ml}$ of antibiotic/antimycotic and was allowed to incubate at $37^{\circ} \mathrm{C}$ in a $5 \% \mathrm{CO}_{2}$ humidified atmosphere incubator.

\section{Cell viability}

A 96-well plate of RAW 264.7 cells $1 \times 10^{4}$ cells/well was incubated overnight (approximately $80 \%$ confluence). Consequently, cells were incubated with KT2 and RT2 $(2-500 \mu \mathrm{g} / \mathrm{ml})$ for $24 \mathrm{~h}$. The cells' viability was assessed using the MTT assay as reported by Maijaroen et al. [17] with modifications. In brief, an aliquot of $10 \mu \mathrm{l}$ of $0.5 \mathrm{mg} /$ $\mathrm{ml}$ MTT solution was pipetted to each well and incubated for $30 \mathrm{~min}$ at $37^{\circ} \mathrm{C}$. After that, the solution was removed. Dimethyl sulfoxide was used to suspend the formazan product. Then, the absorbance at $550 \mathrm{~nm}$ was evaluated. As a result, the viability of non-treated cells or cells treated with $100 \mathrm{ng} / \mathrm{ml}$ LPS was calculated to be $100 \%$.

\section{Evaluation of nitric oxide}

The inflammation of RAW 264.7 cells was inducted using $100 \mathrm{ng} / \mathrm{ml}$ LPS. Concisely, the inflamed cells were further treated with or without peptides $(5-30 \mu \mathrm{g} / \mathrm{ml})$ co-incubated for $24 \mathrm{~h}$ at $37^{\circ} \mathrm{C}$. Then, $100 \mu \mathrm{l}$ of Griess reagent was mixed thoroughly with $100 \mu \mathrm{l}$ of culture medium. The mixing solution was incubated for $10 \mathrm{~min}$ at room temperature. After that, the determination of absorbance at $540 \mathrm{~nm}$ was carried out employing a microplate reader (BioRad, Model 680, CA, USA).

\section{Molecular docking of LPS-bound peptides}

The molecular docking of KT2 and RT2 bound to LPS was performed using GOLD Suite 5.5 (Cambridge, UK) [18]. The peptide was constructed in the PEP-FOLD Peptide Structure Prediction Server (http://bioserv.rpbs. univ-paris-diderot.fr/services/PEP-FOLD/), and the modification of C-terminal carboxylic group to amino group was carried out using Discovery Studio 2017 R2 Client (Dassault Systèmes BIOVIA, BIOVIA Workbook, Release 2017) [19]. The Protein Databank was used to receive the LPS structure (ID: 1QFG), which was set a receptor. The automated molecular docking was performed by setting the binding site with a radius of $20 \AA$ from the $\mathrm{H} 2$ atom of the glucosamine II in lipid A and the backbone of the peptide was fixed to rigid, whereas the side chains of the peptide were flexible [20]. The GOLD score was used as the scoring function with 1000 
GA, and all other parameters were defaults. The possible interaction between peptide and LPS was obtained from the complex with the highest score.

\section{Determination of pro-inflammatory cytokine production levels in LPS-induced RAW 264.7 cells}

The Biotrak ${ }^{\text {TM }}$ ELISA kit (GE Healthcare, IL, USA) was used to quantify the concentration of secreted interleukin-1 $\beta$ (IL-1 $\beta$ ), IL-6, and tumor necrosis factor- $\alpha$ (TNF- $\alpha$ ) according to the manufacturer's protocol [21]. Briefly, cell culture supernatants were added to 96-well plates that were first coated with a capture antibody against each respective cytokine. After the detection antibody was added, avidin-horseradish peroxidase and TMB substrate solution were sequentially added and incubated for $30 \mathrm{~min}$ each. Then, the reaction was stopped by the addition of $100 \mu \mathrm{l}$ stop solution. The reaction plates were read at absorbances of $450 \mathrm{~nm}$ and $570 \mathrm{~nm}$ using a microplate spectrophotometer. The unknown cytokine concentration was calculated using each corresponding cytokine standard curve.

\section{Extraction of total RNA and CDNA synthesis}

RAW 264.7 cells $\left(3 \times 10^{5}\right.$ cells/well $)$ in a 12-well plate were cultivated overnight (approximately $80 \%$ confluence). Afterward, LPS at a concentration of $100 \mathrm{ng} /$ $\mathrm{ml}$ was co-incubated with or without peptides $(5,15$, and $30 \mu \mathrm{g} / \mathrm{ml} \mathrm{KT2}$ or RT2) for $12 \mathrm{~h}$. Cells were washed twice with phosphate-buffered saline (PBS, pH 7.4) and mechanically harvested by scraping. TRIzol ${ }^{\circledR}$ reagent (Invitrogen, CA, USA) was used for RNA extraction, and prior cDNA synthesis was conducted with a RevertAid First Strand cDNA Synthesis Kit (Thermo Fisher Scientific, MA, USA) as specified by manufacturer's protocol, before the reagent was applied to the cDNA template for real-time PCR amplification.

\section{Gene expression quantification}

Real-time PCR was done according to the manufacturer's protocol using an Applied Biosystems 7300 Real-time PCR System (Applied Biosystems, MA, USA). Briefly, $10 \mu \mathrm{l}$ of PCR reaction mixture was mixed thoroughly with $10 \mathrm{ng}$ of cDNA template, $5 \mu \mathrm{M}$ gene-specific forward and reverse primers (Additional file 1: Table S1), and $5 \mu$ of Power SYBR ${ }^{\circledR}$ Green PCR Master Mix (Applied Biosystems, MA, USA). Then, the PCR product was generated using a standard protocol: $95{ }^{\circ} \mathrm{C}$ for $5 \mathrm{~min}$, then 35 amplification cycles of $95^{\circ} \mathrm{C}$ for $45 \mathrm{~s}$ each, $30 \mathrm{~s}$ at each annealing temperature, and $72{ }^{\circ} \mathrm{C}$ for $30 \mathrm{~s}$. After completion, a melting curve was recorded by cooling to $37^{\circ} \mathrm{C}$ for $5 \mathrm{~min}$. The expression levels of PCR products were normalized using glyceraldehyde 3-phosphate dehydrogenase as a control. The gene expression levels of untreated cells [peptide(-)/LPS(-)] was used as a negative control. The relative changes in gene expression were calculated according to Livak and Schmittgen [22].

\section{Western blot analysis}

The RAW 264.7 cells seeded at $3 \times 10^{5}$ cells/well in a 12-well plate were prepared for attachment (approximately $80 \%$ confluence). Then, $100 \mathrm{ng} / \mathrm{ml}$ of LPS co-incubation with and without peptides $(5,15$, and $30 \mu \mathrm{g} / \mathrm{ml}$ KT2 or RT2) was performed. Cells were harvested after $12 \mathrm{~h}$ of incubation. Harvested cells were washed with PBS (pH 7.4) and lysed using radioimmuno-precipitation assay buffer. Twenty micrograms of protein samples were separated by $10 \%$ sodium dodecyl sulfate-polyacrylamide gel electrophoresis. The separated proteins were blotted onto a polyvinylidene fluoride membrane (Whatman, Dassel, Germany). Nonspecific binding proteins were blocked by incubation of membranes in 5\% skim milk for $1 \mathrm{~h}$ at room temperature. Then, membranes were treated with primary antibodies against phospho-p44/42 mitogen-activated protein kinase (MAPK) (Erk1/2), total p44/42 MAPK (Erk1/Erk2), and phospho-p38 MAPK (dilution 1:2000, 1:2000, and 1:2000, respectively; Cell Signaling Technology, MA, USA); total p38 MAPK and NF-KB p65 (1:2000 and 1:1000, respectively; Abcam, Shanghai, China); and phospho-c-Jun N-terminal protein kinase (JNK) and total JNK (1:500 and 1:200, respectively; BioLegend, CA, USA) at $4{ }^{\circ} \mathrm{C}$ overnight with slow shaking. Mouse anti-human $\beta$-actin was used as a control (1:10,000; Sigma-Aldrich; MO, USA). Then, the membranes were treated with secondary antibodies, including rabbit anti-mouse (1:3000) and mouse anti-mouse (1:20,000; both from Thermo Fisher Scientific, MA, USA) at room temperature for $2 \mathrm{~h}$. The membranes were incubated in enhanced chemiluminescence reagent (SigmaAldrich; MO, USA). The apparent density of the bands on membranes was captured by an ImageQuant ${ }^{\mathrm{TM}}$ Imager (GE Healthcare, IL, USA).

\section{Measurement of apoptotic cells}

Apoptotic cell measurement was achieved using flow cytometry [17]. In brief, the treated inflamed cells (in 12-well plate) after $24 \mathrm{~h}$ incubation were harvested and re-suspended to a final density of $1 \times 10^{6} \mathrm{cells} / \mathrm{ml}$ in $200 \mu \mathrm{l}$ of binding buffer and further stained by mixing with $5 \mu \mathrm{l}$ of fluorescein isothiocyanate (FITC) conjugated annexin $\mathrm{V}$ and $10 \mu \mathrm{l}$ of propidium iodide (PI) for $15 \mathrm{~min}$ at room temperature. At least 10,000 cells were injected to a flow cytometer (BD FACSCanto ${ }^{\mathrm{TM}}$ II, BD Biosciences, CA, USA) within $1 \mathrm{~h}$ after staining. The stained cells were divided into four populations after identification: Annexin V-FITC(-)/PI(-), Annexin V-FITC(+)/PI(-), Annexin V-FITC $(+) / \mathrm{PI}(+)$, and Annexin V-FITC(-)/ 
$\mathrm{PI}(+)$, which were considered as living cells, early apoptotic cells, late apoptotic cells, and dead cells, respectively. The percentages of each population and total apoptosis was calculated according to Eqs. 1 and 2, respectively.

$$
\text { Population }=\frac{\mathrm{N}_{\text {pop }}}{\mathrm{N}_{\text {total }}} \times 100
$$

$$
\text { Total apoptosis }=\text { Population }_{\text {early }}+\text { Population }_{\text {late }}
$$

where $\mathrm{N}_{\text {pop }}$ and $\mathrm{N}_{\text {total }}$ are the number of cells from each individual population and the total population, respectively, and Population ${ }_{\text {early }}$ and Population late $_{\text {are the per- }}$ centages of the populations of the early apoptotic phase and late apoptosis phase, respectively.

\section{Intracellular ROS levels assessment}

The probe 2', 7'-dichlorodihydrofluorescein diacetate $\left(\mathrm{H}_{2}\right.$ DCFDA $)$ was used to evaluate intracellular ROS levels. The evaluation was performed as stated by Hernández-Ledesma et al. [12] with modifications. Briefly, the treated inflamed cells (in 12-well plates) at $24 \mathrm{~h}$ were harvested and suspended in PBS ( $\mathrm{pH}$ 7.4). Ten micromolar $\mathrm{H}_{2}$ DCFDA was mixed thoroughly with suspended cells and incubated in the dark for $30 \mathrm{~min}\left(37^{\circ} \mathrm{C}\right)$ before ROS levels were measured with a flow cytometer (BD FACSCanto $^{\mathrm{TM}}$ II, BD Biosciences, CA, USA).

\section{Statistical analysis}

All results were analyzed from the averaged data of triplicate experiments, and the data are expressed as the mean \pm standard deviation (SD). Statistical significance was evaluated with analysis of variance (ANOVA) followed by the Duncan test using SPSS 16.0 (SPSS Inc., IL, USA). A $p$ value of $<0.05$ was considered statistically significant and shown with different lowercase letters on the top of each bar in the figures.

\section{Results}

\section{Cell viability}

KT2 and RT2 did not influence cell viability at a concentration up to 62.5 and $250 \mu \mathrm{g} / \mathrm{ml}$, respectively. However, KT2 and RT2 reduced RAW 264.7 cell survival to 72 and $79 \%$ at concentrations of 125 and $500 \mu \mathrm{g} / \mathrm{ml}$, respectively (Additional file 1: Fig. S2). In addition, KT2 and RT2 at a concentration ranging between 5 and $30 \mu \mathrm{g} / \mathrm{ml}$ did not have negative effects on LPS-stimulated RAW 264.7 cells Additional file 1: Fig. S3).

\section{Effect of peptides on nitric oxide production in inflamed RAW 264.7 cells}

Generation of nitric oxide (NO) was considerably upregulated in the LPS-treated group, compared with the

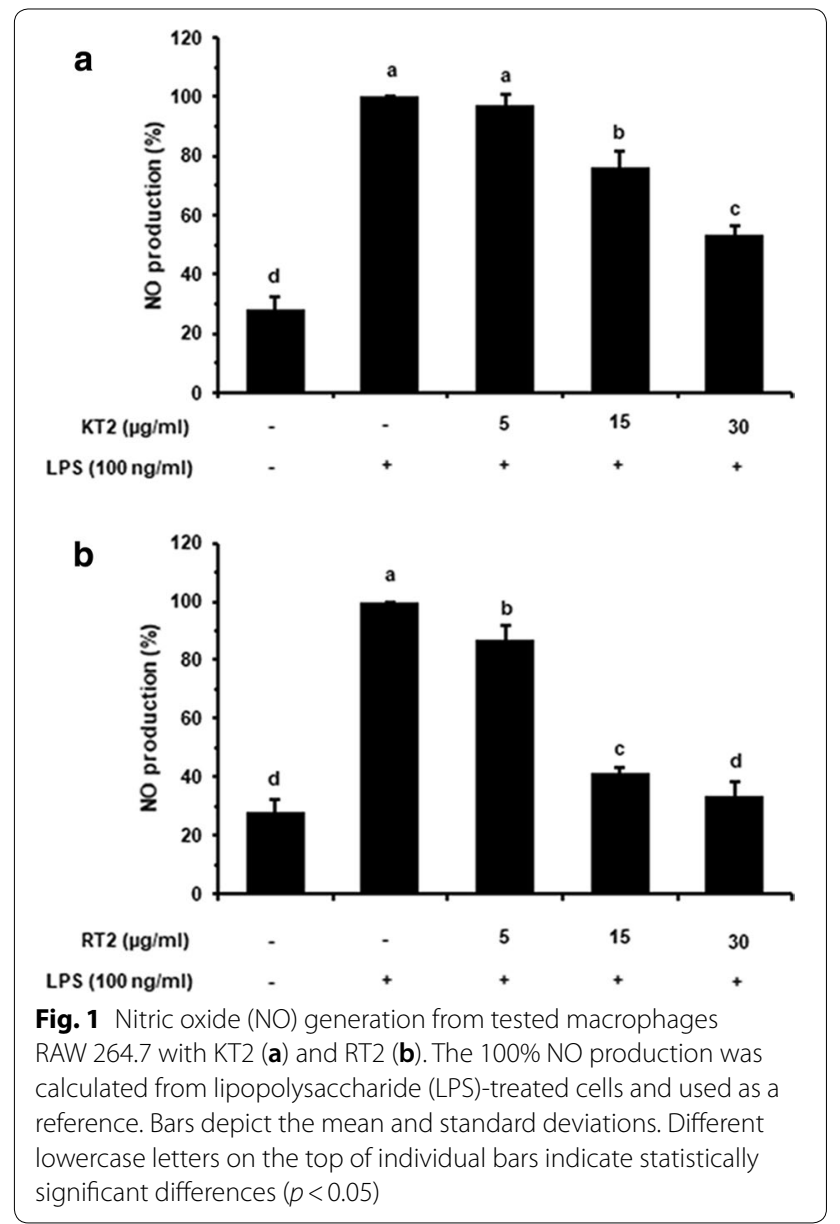

non-stimulated cells (Fig. 1). Despite that, inflamed RAW 264.7 cells treated with KT2 and RT2 (at concentrations ranging from $15 \mu \mathrm{g} / \mathrm{ml}$ of KT2 and $5 \mu \mathrm{g} / \mathrm{ml}$ of RT2) exhibited meaningful declines in the triggering of $\mathrm{NO}$ production. Residual NO production ranging between 97.5 and $53.5 \%$ (Fig. 1a) and 87.2 and $33.5 \%$ (Fig. 1b) was obtained after treatment with different concentrations $(5-30 \mu \mathrm{g} / \mathrm{ml})$ of KT2 and RT2, respectively.

\section{Structural modeling of the peptides and LPS complex}

To obtain further information on peptide-LPS interactions, in silico model structure predictions were performed. KT2-LPS and RT2-LPS complexes are shown as Fig. 2a, b, respectively. First, 11 interactions of the KT2-LPS complex were detected between critical amino acid residues and LPS (Additional file 1: Table S2). In detail, Asn1 used its amino group to form an electrostatic interaction with 3-deoxy- $\alpha$ D-manno-octulosonic acid (KDO) at the inner core of LPS. Furthermore, Trp10 bound to a fatty acid of lipid A of LPS via hydrophobic interaction. Meanwhile, the side chains of all critical amino acid residues, including Asn1, Gln4, Lys6, Trp10, Lys11, Trp13, and Lys14, form 9 hydrogen bonds 


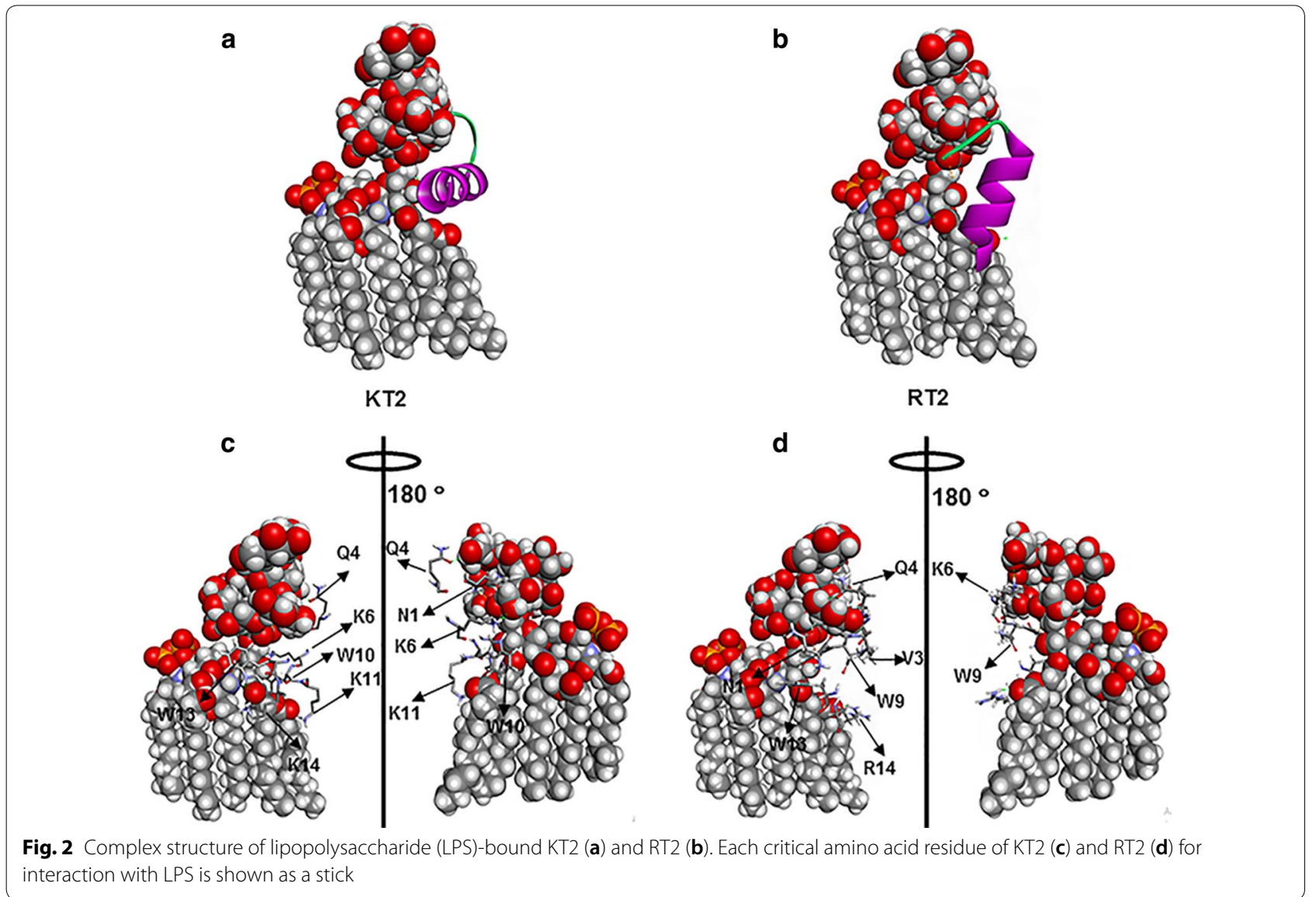

with LPS (Fig. 2c, and Additional file 1: Table S2). The model structure of RT2-LPS also demonstrated the interaction of the side chains of 7 critical amino acid residues, including Asn1, Val3, Gln4, Lys6, Trp9, Trp13, and Arg14 residues bound to LPS, resulting in 1 electrostatic interaction between Trp9 and KDO of LPS (Pi-anion interaction) and 12 hydrogen bonds (other critical amino acid residues) (Fig. 2d, Additional file 1: Table S2).

\section{Effect of peptides on pro-inflammatory cytokine production levels in inflamed RAW 264.7 cells}

The inflammatory markers, IL-1 $\beta$, IL- 6 , and TNF- $\alpha$, secreted from RAW 264.7 cells were produced significantly after activation with LPS (Fig. 3). The results show that KT2 could inhibit IL-1 $\beta$ at a concentration of $5 \mu \mathrm{g} / \mathrm{ml}$, with no significant difference in cells treated with $15 \mu \mathrm{g} / \mathrm{ml} \mathrm{KT2}$. Regardless, when the peptide's concentration was increased to $30 \mu \mathrm{g} / \mathrm{ml}$, the IL-1 $\beta$ production was markedly reduced to $18.8 \%$ (Fig. 3a). However, RT2 at a concentration of $5 \mu \mathrm{g} /$ $\mathrm{ml}$ could not substantially inhibit IL-1 $\beta$ production, while 15 and $30 \mu \mathrm{g} / \mathrm{ml}$ of RT2 co-incubation could decrease the generation of IL-1 $\beta$ to 68 and 15\%, respectively (Fig. 3b). Meanwhile, the generation of IL-6 in inflamed RAW 264.7 cells was reduced to $92.8,68.8$, and $58.8 \%$ and $66.8,27.3$, and $11 \%$ after treatment with KT2 and RT2 at concentrations of 5,15 , and $30 \mu \mathrm{g} / \mathrm{ml}$, respectively (Fig. 3c, d). Furthermore, TNF- $\alpha$ generation was also inhibited in inflamed RAW 264.7 cells. In cells treated with $30 \mu \mathrm{g} / \mathrm{ml}$ of KT2 or RT2, TNF- $\alpha$ production decreased to 24.2 and $28.9 \%$, respectively (Fig. 3e, f).

Effect of peptides on inhibition of iNOS, TNF- $a$, STAT1, JNK-1, NF-KB, and p38 MAPK expression

Activation of macrophages with LPS caused a strong increase in mRNA expression levels of inducible nitric oxide synthase (iNOS), TNF- $\alpha$, signal transducer and activator of transcription 1 (STAT1), JNK-1, NF-kB, and p38 MAPK (Fig. 4). A dose-related decrease in iNOS and TNF- $\alpha$ mRNA expression was noted in cells treated with KT2 and RT2 (Fig. 4a, b). The mRNA expression levels of iNOS in cells treated with 5,15 , and $30 \mu \mathrm{g} / \mathrm{ml}$ were $2.7-$, 1.6-, and 1.2-fold (KT2 peptide treatment; Fig. 4a) and 2.7-, 1.5-, and 1.4-fold (RT2 peptide treatment; Fig. 4a), respectively, while LPS-stimulated cells produce iNOS mRNA at 4.0-fold compared with untreated cells. In addition, TNF- $\alpha$ mRNA expression levels in cells incubated with 5 , 


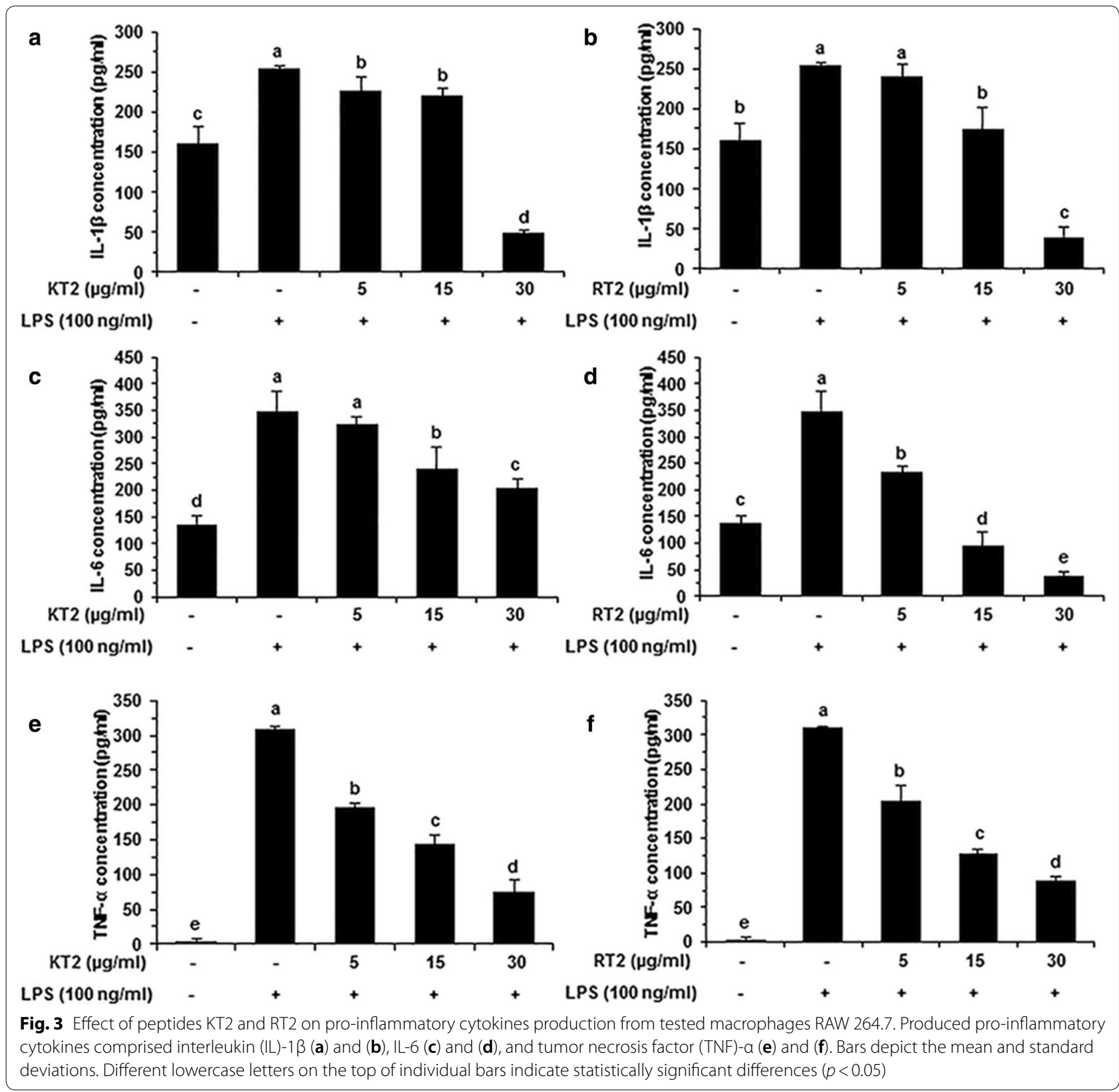

15 , and $30 \mu \mathrm{g} / \mathrm{ml} \mathrm{KT} 2$ and RT2 were 1.7-, 1.5-, and 1.1-fold (Fig. 4b) and 1.7-, 1.6-, and 1.4-fold (Fig. 4b), respectively, while LPS-stimulated cells produced TNF- $\alpha$ mRNA at 3.1fold compared with untreated cells (Fig. 4b). In parallel, KT2 and RT2 could also inhibit inflammatory transcription factors (STAT1 and NF-kB), JNK-1, and p38 MAPK mRNA expression levels. With regard to STAT1, JNK-1, NF- $\mathrm{kB}$, and p38 MAPK, the treatment of KT2 and RT2 could at least preserve the mRNA expression at 1.4- and 1.3-fold (Fig. 4c), 1.8- and fourfold (Fig. 4d), 1.3- and 1.3fold (Fig. 4e), and 1.2- and 2.8-fold (Fig. 4f), respectively. Western blot analysis confirmed that peptides could reduce inflammatory protein expressions (Fig. 5). The results demonstrate that peptides reduce phosphorylation of JNK (Fig. 5a, b), p38 MAPK (Fig. 5a, c), and NF-кB p65 (Fig. 5a, d) in a dose-dependent manner.

\section{Effect of peptides on up-regulation of ERK and MKP-1 expression}

LPS-stimulated macrophages treated with co-incubation of KT2 and RT2 resulted in a strong increase of mRNA expression levels of extracellular signal-regulated kinase (ERK) compared with the mRNA expression of LPSstimulated cells (Fig. 6a, b). In detail, ERK mRNA expression levels in cells treated with 5,15 , and $30 \mu \mathrm{g} / \mathrm{ml}$ of KT2 increased 1.0-, 1.5-, and 5.1-fold, respectively, compared 


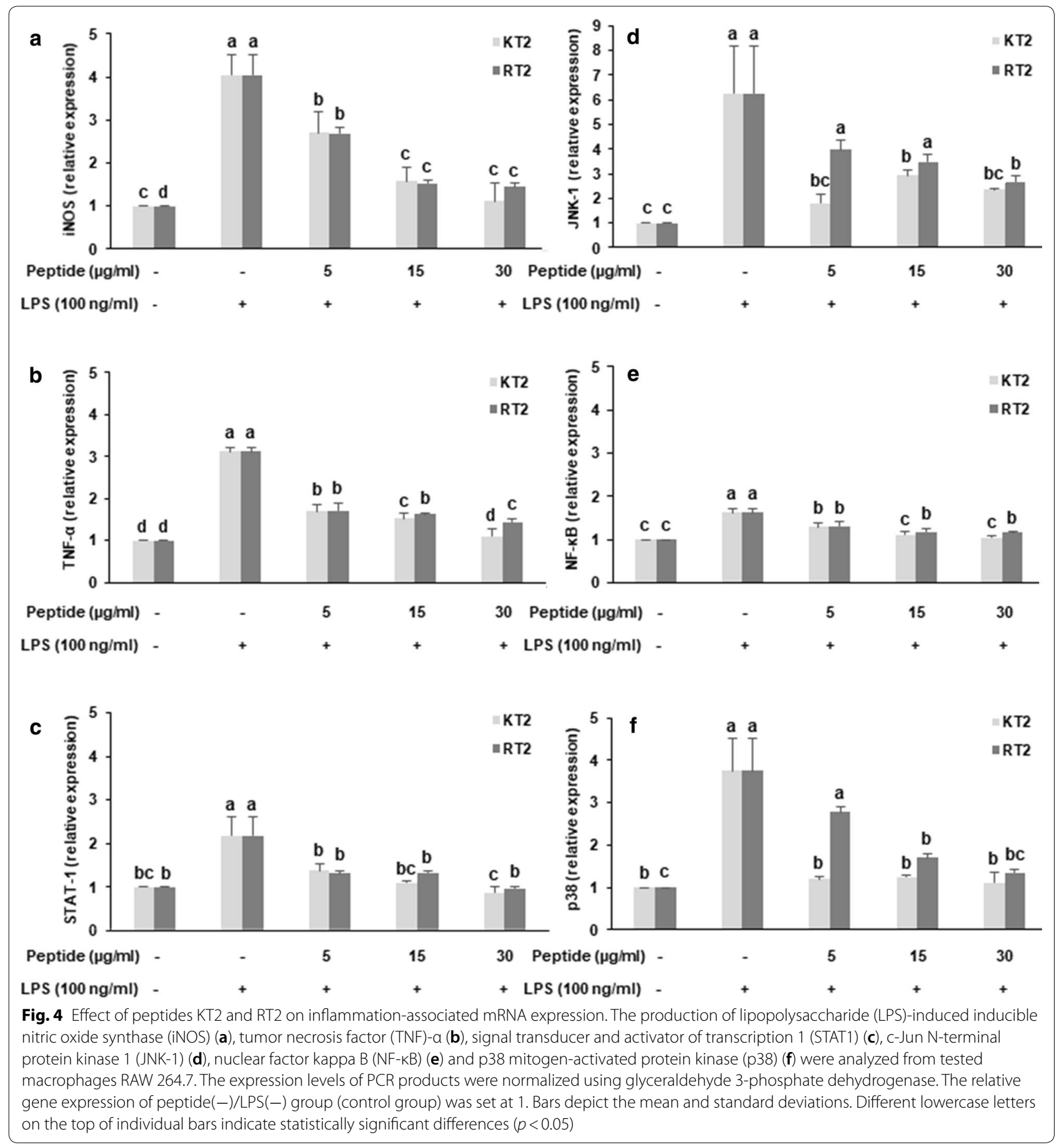

with untreated RAW 264.7 cells (Fig. 6a). The highest ERK mRNA expression level was up-regulated up to 1.7 -fold after treatment with $30 \mu \mathrm{g} / \mathrm{ml}$ of RT2 (Fig. 6b). This result correlated with protein expression (Fig. 5a, e). A strong increase of phosphorylated ERK was detected by western blotting analysis (Fig. 5a, e). Furthermore, MAPK phosphatase-1 (MKP-1) mRNA expression levels in LPS-stimulated cells treated with KT2 and RT2 were also up-regulated up to 1.8- and 2.3-fold at a peptide concentration of $30 \mu \mathrm{g} / \mathrm{ml}$, while MKP-1 mRNA expression in LPS-stimulated cells was lower than that in untreated cells by 0.7 -fold (Fig. 6c, d). 


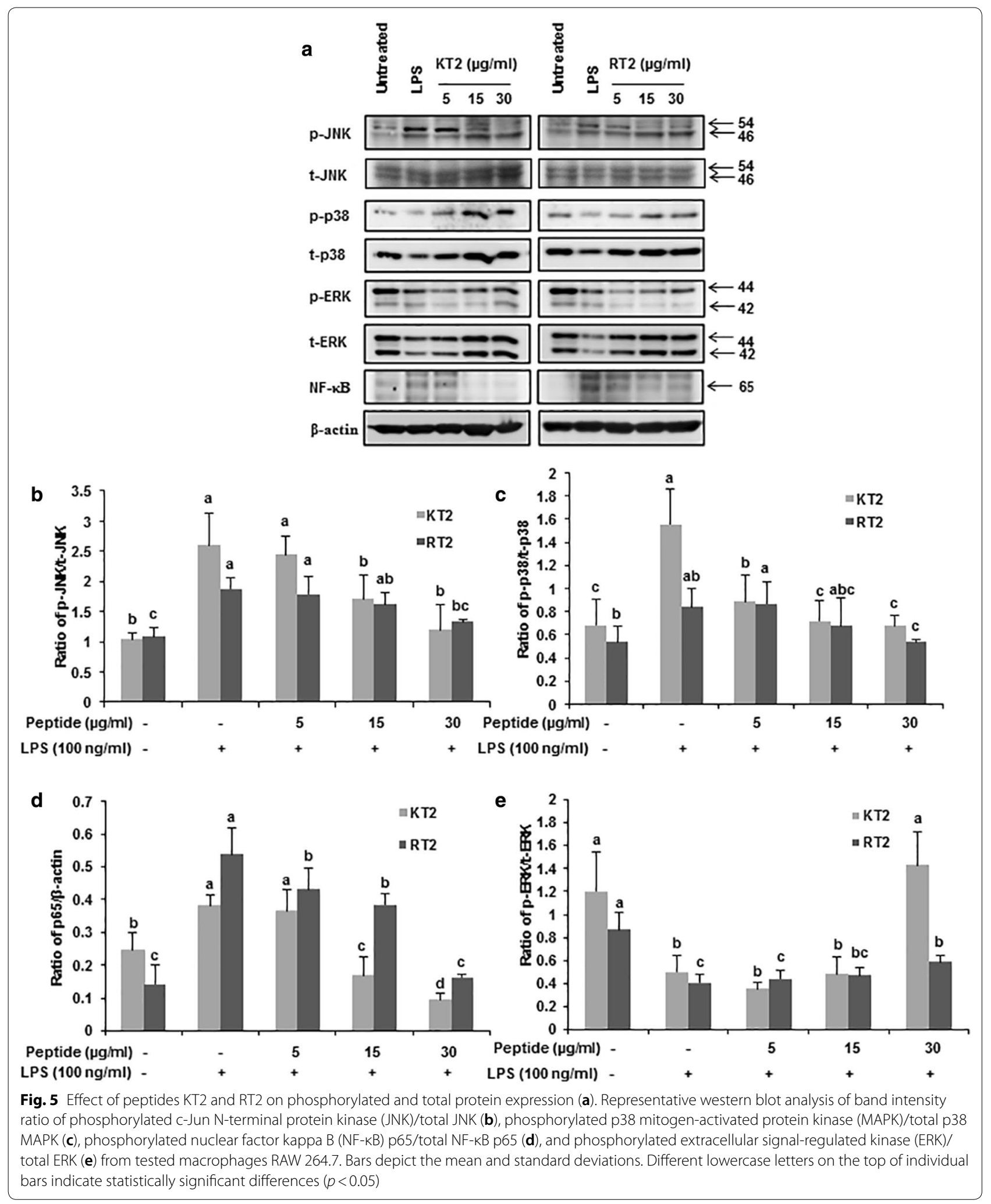



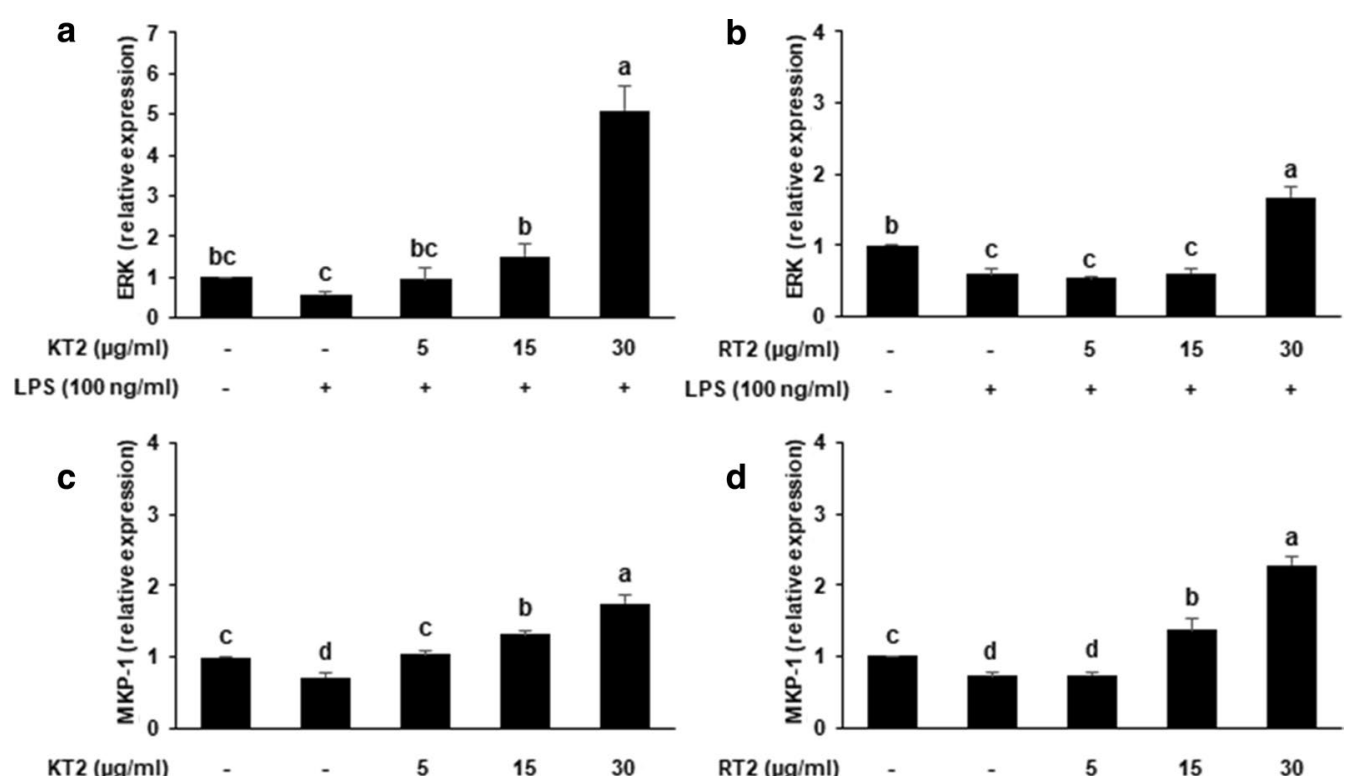

$\operatorname{LPS}(\mathbf{1 0 0} \mathrm{ng} / \mathrm{ml}) \quad-\quad+\quad+\quad+\quad+$

d

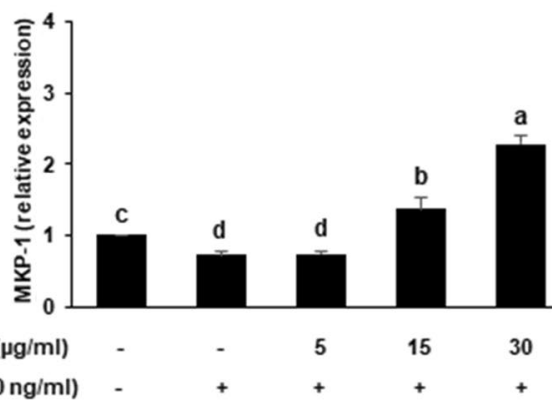

Fig. 6 Effect of peptides KT2 and RT2 on anti-inflammation-associated mRNA expression. The production of extracellular signal-regulated kinase (ERK) (a, b) and mitogen-activated protein kinase phosphatase-1 (MKP-1) (c, d) were analyzed from tested macrophages RAW 264.7. The expression levels of PCR products were normalized using glyceraldehyde 3-phosphate dehydrogenase. The relative gene expression of peptide(-)/LPS(-) group (control group) was set at 1. Bars depict the mean and standard deviations. Different lowercase letters on the top of individual bars indicate statistically significant differences $(p<0.05)$

\section{Intracellular ROS generation}

The fluorescent dye $\mathrm{H}_{2}$ DCFDA was employed to assess ROS levels in tested cells. As demonstrated in Fig. 7, inflamed RAW 264.7 cells generated the highest amount of intracellular ROS, which results in increased fluorescence intensity. The result demonstrates that LPSinduced cells produced the highest ROS level by 3.4-fold over the untreated cells (Fig. 7a, b). Meanwhile, the intracellular ROS production levels in all peptide treatment groups were considerably decreased as compared with the LPS treatment group (Fig. 7a, b). Among tested peptides, KT2 at a concentration of $15 \mu \mathrm{g} / \mathrm{ml}$ could reduce ROS in LPS-stimulated cells by 4.2-fold (Fig. 7a). In addition, RT2 at the same concentration $(15 \mu \mathrm{g} / \mathrm{ml})$ could reduce ROS levels by 4.8-fold (Fig. 7b).

\section{Apoptosis analysis}

Flow cytometry using a double-staining assay revealed the anti-apoptosis activity of the peptides against inflamed RAW 264.7 cells (Figs. 8 and 9). In detail, the results demonstrated that LPS markedly increased RAW 264.7 cell apoptosis to $2.6 \pm 0.5 \%$ (early apoptosis) and $19.4 \pm 2.2 \%$ (total apoptosis) (Figs. 8b, f and 9b, f). However, when inflamed cells were incubated with KT2 and RT2, they markedly reduced RAW 264.7 cell apoptosis. The early and total apoptotic cells constituted up to

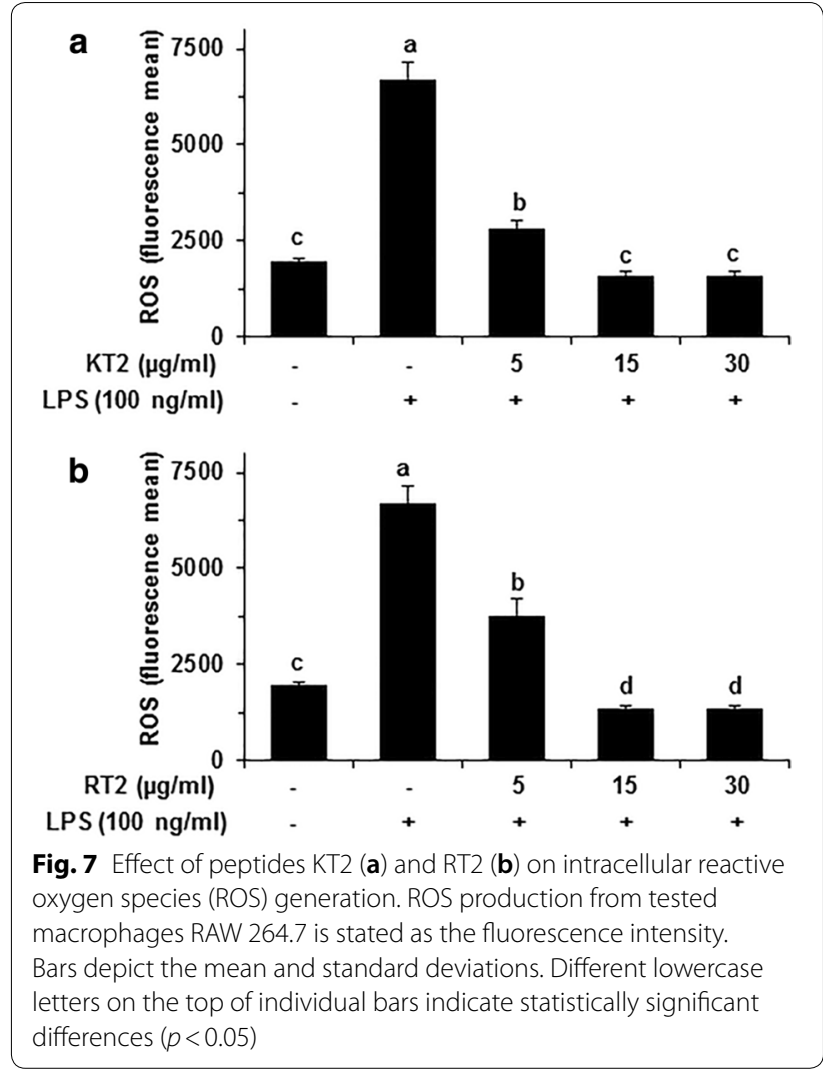




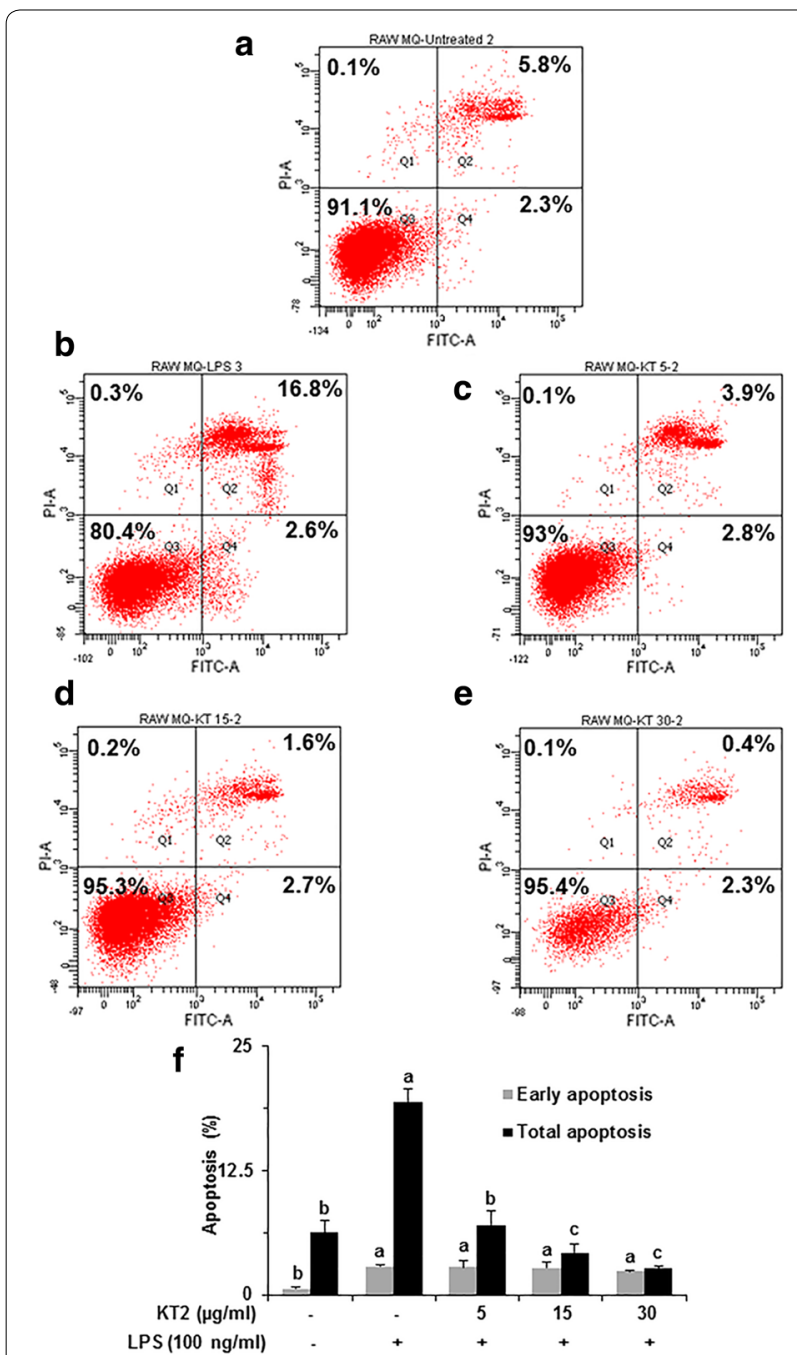

Fig. 8 Anti-apoptosis activity of KT2. Apoptotic cells of tested macrophages RAW 264.7 were assigned by Annexin V-FITC/ propidium iodide (PI) staining and investigated by flow cytometry. Profiles of Annexin V-FITC/PI staining of untreated cells (a), inflamed cells (b), inflamed cells treated with $5 \mu \mathrm{g} / \mathrm{ml}$ of KT2 (c), inflamed cells treated with $15 \mu \mathrm{g} / \mathrm{ml}$ of KT2 (d), and inflamed cells treated with $30 \mu \mathrm{g} / \mathrm{ml}$ of KT2 (e) are shown. Representative percentages of apoptotic cells, where the population of cells stained by Annexin V-FITC(+)/PI(-) and Annexin V-FITC $(+) / P I(+)$ were indicated as early and late apoptosis, respectively. Total apoptosis is indicated as the sum of percentages of early and late apoptosis (f). Bars depict the mean and standard deviations. Different lowercase letters on the top of individual bars indicate statistically significant differences $(p<0.05)$

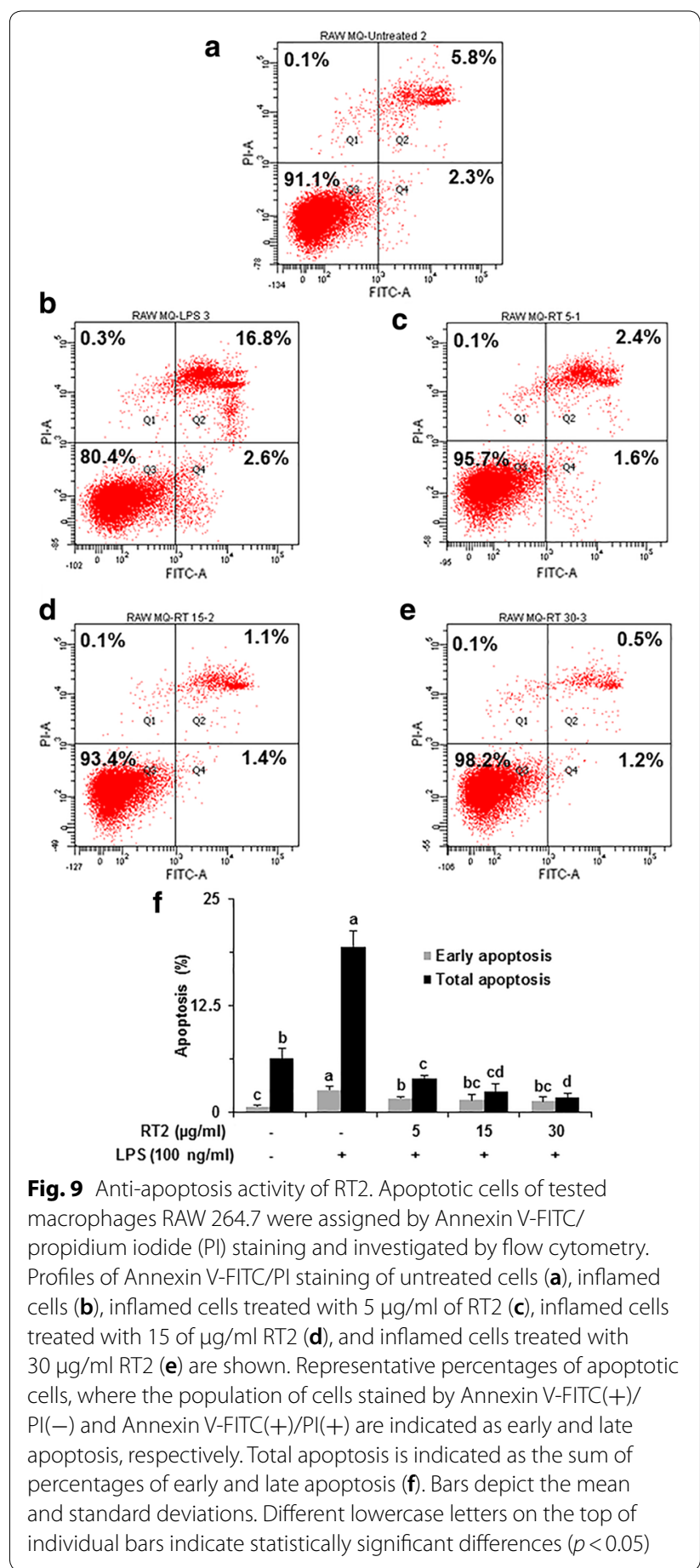

\section{Discussion}

Previously, the cationic peptides KT2 and RT2 have displayed broad antibacterial and anti-cancer activity [14-17]. Other studies indicated that some cationic peptides not only exhibit antimicrobial action but also suppress the inflammation initiated by bacteria [23-25]. This might result from the positively charged and $1.2 \pm 0.49 \%$ and $1.7 \pm 0.55 \%(30 \mu \mathrm{g} / \mathrm{ml}$ of RT2; Fig. $9 \mathrm{e}$, f), respectively. 
peptides interacting with LPS and blocking LPS-binding protein [26]. However, other anti-inflammatory mechanisms have also been proposed, which usually implicate the alteration of gene and protein expression levels [27-29]. The primary results of this study demonstrated that KT2 and RT2 could suppress production levels of NO (Fig. 1) and other inflammatory markers, including IL- $1 \beta$, TNF- $\alpha$, and IL- 6 , secreted from inflamed RAW 264.7 cells (Fig. 3) by forming a peptide-LPS complex that may obstruct the LPS-binding protein (Fig. 2). In detail, the positively charged amino acids attract LPS through electrostatic interactions. Hydrophobic interaction resulting from hydrophobic amino acids is necessary for the engagement between LPS (acryl chain of lipid A) and peptides. Apart from those hydrophobic amino acids, basic amino acids are also required for LPS binding to peptides. Correspondingly, the indole ring of Trp was positioned close to the acyl chain of lipid A [30]. This evidence agreed with our findings. As mentioned before, however, the antiinflammatory feature of cationic peptides may result from changes in the inflammation mechanisms. Hence, genes and proteins that are involved in inflammatory response pathways have been elucidated. In terms of inflammatory processes, the MAPK pathways and the pathway resulting in the activation of NF- $\mathrm{KB}$ represent the major intracellular pathways that indicate the degree of inflammation from inflamed cells. ERK1/2, JNK, and p38 MAPK regulate MAPK cascades through phosphorylation $[31,32]$. The results indicated that both peptide treatments could significantly suppress the transcription and translation of JNK-1 (Figs. 4d and $5 \mathrm{~b}$ ) and $\mathrm{p} 38$ MAPK (Figs. 4f and 5c) mRNA and protein expression, respectively. Follow-up studies indicated that JNK-1 and p38 MAPK seems to be substantially effective for AP-1 and NF-kB [31, 33, 34], respectively. Thus, the down-regulation of the gene and protein expression of pro-inflammatory cytokines (Figs. 3 and $4 \mathrm{a}, \mathrm{b}$ ) and NF-kB (Figs. 4e and $5 \mathrm{~d}$ ) result from the down-regulation of JNK-1 and p38 MAPK. Interestingly, the peptide treatment could enhance the generation of ERK (Figs. 5e and 6a, b) and MKP-1 (Fig. 6c, d) in inflamed RAW 264.7 cells. Recent validation indicates the novel role of ERK as a crucial key anti-inflammatory molecule via affecting the promotion of c-Fos translocation [35]. Mice and macrophages lacking c-Fos (Fos-/-) revealed a decrease in production of IL-10, an anti-inflammatory cytokine, while the role of NF- $\mathrm{kB}$ was activated [36]. Also, MKP-1, an inducible nuclear phosphatase, has been demonstrated to stimulate many anti-inflammatory effects. It acts as a negative feedback regulator to limit p38 MAPK and JNK activity by the dephosphorylation process. An affirmation indicated that activation of ERK could actuate MKP-1 and thus down-regulate p38 MAPK [37]. These previous results confirm our findings very well.

Simultaneously, inflammation resulting from bacterial infection has been shown to cause excessive generation of ROS in RAW 264.7 by the involvement of mitochondria [38, 39]. Our results demonstrate that KT2 and RT2 also display anti-oxidative stress activity by suppression of ROS generation (Fig. 7). The reduced ROS generation results from the suppression of production of pro-inflammatory cytokines (IL-1 $\beta$ and TNF- $\alpha$ ) in peptide-treated cells [40]. Also, ROS provide positive feedback to STAT1 [41]. The results show that both peptide treatments suppressed mRNA expression of STAT1 in a dose-dependent manner (Fig. 4c). In addition, ROS accumulation stimulates the transcription factor AP-1 and leads to cell apoptosis [42]. Consistent with the down-regulation of ROS production, treatment with both peptides decreased the total apoptosis levels of inflamed cells (Figs. 8 and 9). This resulted from a reduction in the loss of cell membrane integrity, which reduced early apoptosis [Annexin V-FITC $(+) / P I(-)]$, and an increase in the PI exclusion ability of cells, which reduced late apoptosis [Annexin V-FITC $(+) / P I(+)$ ] [43]. This observational evidence

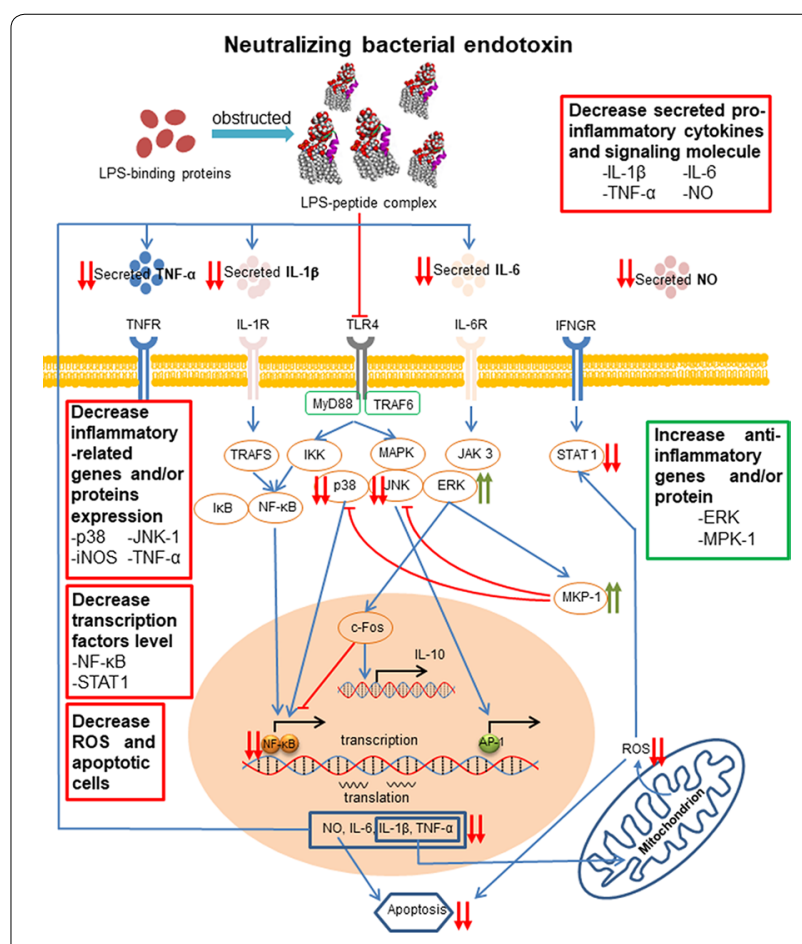

Fig. 10 Graphical summary of multi-functional KT2 and RT2 peptide inflammation-associated properties, including anti-inflammation, anti-oxidative stress, and anti-apoptosis activity, as shown by LPS-stimulated macrophage RAW 264.7 cells 
indicated that both peptides are able to suppress LPSstimulated ROS and neutralize ROS-induced oxidative damage in RAW 264.7 cells.

The collective interrelation of the anti-inflammatory response, anti-oxidative stress reduction, and antiapoptosis activity of these peptides is summarized in Fig. 10. To the best of our knowledge, this is the first report indicating that KT2 and RT2 can serve as multifunctional cationic peptides that may provide a new medical approach for challenging infection and inflammation-related diseases (Additional file 1: Fig. S1).

\section{Supplementary information}

Supplementary information accompanies this paper at https://doi. org/10.1186/s13765-019-0488-3.

Additional file 1: Fig. S1. Promising strategy for the use of multifunctional peptides for treating infection-related diseases. Table S1. Primers and amplification condition used for real-time PCR. Fig. S2. Effect of peptides KT2 (a) and RT2 (b) on macrophage RAW 264.7 cells' viability. The viability of untreated cells with each corresponding peptide has been taken as a reference (100\%). Bars represent the mean and standard deviations. Different lowercase letters on the top of individual bars indicate statistically significant differences $(p<0.05)$. Fig. S3. Effect of peptides KT2 (a) and RT2 (b) on LPS-stimulated macrophage RAW 264.7 cells'viability. The viability of LPS-treated cells [peptide $(-) / \mathrm{LPS}(+)$ ] has been taken as a reference (100\%). Bars represent the mean and standard deviations. Different lowercase letters on the top of individual bars indicate statistically significant differences $(p<0.05)$. Table S2. Comparison of sequence and attribute of critical residues and molecules of peptide-LPS complex

\section{Acknowledgements}

We would like to express our gratitude to Assoc. Prof. Kiattawee Choowongkomon for their GOLD docking technique supports.

\section{Authors' contributions}

WP, AJ, ST and BN performed the experiments, analyzed the data and wrote the manuscript. NJ and SK advised the work and amended the manuscript. All authors read and approved the final manuscript.

\section{Funding}

This work was supported by the National Research University (NRU) (Grant No. NRU581004) and the Protein and Proteomics Research Center for Commercial and Industrial Purposes (ProCCl), Faculty of Science, Khon Kaen University.

\section{Availability of data and materials}

All data generated or analyzed during this study are included in this published article and its supplementary information file.

\section{Competing interest}

The authors declare that they have no competing interests.

\footnotetext{
Author details

1 Protein and Proteomics Research Center for Commercial and Industrial Purposes (ProCCl), Faculty of Science, Khon Kaen University, Khon Kaen 40002, Thailand. ${ }^{2}$ Department of Biochemistry, Faculty of Science, Khon Kaen University, Khon Kaen 40002, Thailand. ${ }^{3}$ Department of Biochemistry, Faculty of Medicine, Khon Kaen University, Khon Kaen 40002, Thailand. ${ }^{4}$ Department of Integrated Science, Forensic Science Program, Faculty of Science, Khon Kaen University, Khon Kaen 40002, Thailand.
}

Received: 21 Auqust 2019 Accepted: 30 December 2019 Published online: 21 January 2020

\section{References}

1. Ngkelo A, Mega K, Yeadon M, Adcock I, Kirkham PA (2012) LPS induced inflammatory responses in human peripheral blood mononuclear cells is mediated through NOX4 and $\mathrm{G}_{i}$ a dependent PI-3kinase signalling. J Inflamm 9:1-7

2. Faure E, Thomas L, Xu H, Medvedev A, Equils O, Arditi M (2001) Bacterial lipopolysaccharide and IFN- $\gamma$ induce toll-like receptor 2 and toll-like receptor 4 expression in human endothelial cells: role of NF-KB activation. J Immunol 166:2018-2024

3. Nicholas C, Batra S, Vargo MA, Voss OH, Gavrilin MA, Wewers MD, Guttridge DC, Grotewold E, Doseff Al (2007) Apigenin blocks lipopolysaccharide-induced lethality in vivo and proinflammatory cytokines expression by inactivating NF-kB through the suppression of p65 phosphorylation. J Immunol 179:121-127

4. Bognar E, Sarszegi Z, Szabo A, Debreceni B, Kalman N, Tucsek Z, Sumegi B, Gallyas F Jr (2013) Antioxidant and anti-inflammatory effects in RAW264.7 macrophages of malvidin, a major red wine polyphenol. PLoS One 8(6):e65355

5. Frostegård J, Ulfgren AK, Nyberg P, Hedin U, Swedenborg J, Andersson U, Hansson GK (1999) Cytokine expression in advanced human atherosclerotic plaques: dominance of pro-inflammatory (Th1) and macrophagestimulating cytokines. Atherosclerosis 145:33-43

6. Jara LJ, Medina G, Vera-Lastra O, Amigo MC (2006) Accelerated atherosclerosis, immune response and autoimmune rheumatic diseases. Autoimmun Rev 5:195-201

7. Karin M, Lawrence T, Nizet V (2006) Innate immunity gone awry: linking microbial infections to chronic inflammation and cancer. Cell 124:823-835

8. Sarkar D, Fisher PB (2006) Molecular mechanisms of aging-associated inflammation. Cancer Lett 236:13-23

9. Rayburn ER, Ezell SJ, Zhang R (2009) Anti-inflammatory agents for cancer therapy. Mol Cell Pharmacol 1:29-43

10. Hussain T, Tan B, Yin Y, Blachier F, Tossou MC, Rahu N (2016) Oxidative stress and inflammation: what polyphenols can do for us? Oxid Med Cell Longev. https://doi.org/10.1155/2016/7432797

11. Biswas SK (2016) Does the interdependence between oxidative stress and inflammation explain the antioxidant paradox? Oxid Med Cell Longev. https://doi.org/10.1155/2016/5698931

12. Hernández-Ledesma B, Hsieh CC, de Lumen BO (2009) Antioxidant and anti-inflammatory properties of cancer preventive peptide lunasin in RAW 264.7 macrophages. Biochem Biophys Res Commun 390:803-808

13. Guarna MM, Coulson R, Rubinchik E (2006) Anti-inflammatory activity of cationic peptides: application to the treatment of acne vulgaris. FEMS Microbiol Lett 257:1-6

14. Anunthawan T, Yaraksa N, Phosri S, Theansungnoen T, Daduang S, Dhiravisit A, Thammasirirak S (2013) Improving the antibacterial activity and selectivity of an ultra short peptide by hydrophobic and hydrophilic amino acid stretches. Bioorg Med Chem Lett 23:4657-4662

15. Anunthawan T, de la Fuente-Nùñez $C$, Hancock RE, Klaynongsruang $S$ (2015) Cationic amphipathic peptides KT2 and RT2 are taken up into bacterial cells and kill planktonic and biofilm bacteria. Biochim Biophys Acta 1848:1352-1358

16. Theansungnoen T, Maijaroen S, Jangpromma N, Yaraksa N, Daduang S, Temsiripong T, Daduang S, Klaynongsruang S (2016) Cationic antimicrobial peptides derived from Crocodylus siamensis leukocyte extract, revealing anticancer activity and apoptotic induction on human cervical cancer cells. Protein J 35:202-211

17. Maijaroen S, Jangpromma N, Daduang J, Klaynongsruang S (2018) KT2 and RT2 modified antimicrobial peptides derived from Crocodylus siamensis leucrocin I show activity against human colon cancer HCT-116 cells. Environ Toxicol Pharmacol 62:164-176

18. Jones G, Willett P, Glen RC, Leach AR, Taylor R (1997) Development and validation of a genetic algorithm for flexible docking. J Mol Biol 267:727-748

19. Dassault Systèmes BIOVIA, Workbook BIOVIA (2017) BIOVIA Pipeline Pilot. Dassault Systèmes, San Diego

20. Baek MH, Kamiya M, Kushibiki T, Nakazumi T, Tomisawa S, Abe C, Kumaki Y, Kikukawa T, Demura M, Kawano K, Aizawa T (2016) Lipopolysaccharidebound structure of the antimicrobial peptide cecropin P1 determined by nuclear magnetic resonance spectroscopy. J Pept Sci 22:214-221 
21. Santos Savio A, Machado Diaz AC, Chico Capote A, Miranda Navarro J, Rodríguez Alvarez Y, Bringas Pérez R, Estévez del Toro M, Guillen Nieto GE (2015) Differential expression of pro-inflammatory cytokines IL-15Ralpha, IL-15, IL-6 and TNFalpha in synovial fluid from rheumatoid arthritis patients. BMC Musculoskelet Disord 16:51-58

22. Livak KJ, Schmittgen TD (2004) Analysis of relative gene expression data using real-time quantitative PCR and the $2^{-\triangle \Delta C T}$ method. Methods 25:402-408

23. Finlay BB, Hancock REW (2004) Can innate immunity be enhanced to treat microbial infections? Nat Rev Microbiol 2:497-504

24. Scott MG, Vreugdenhil AC, Buurman WA, Hancock RE, Gold MR (2000) Cutting edge: cationic antimicrobial peptides block the binding of lipopolysaccharide (LPS) to LPS binding protein. J Immunol 164:549-553

25. Sun Y, Shang D (2015) Inhibitory effects of antimicrobial peptides on lipopolysaccharide-induced inflammation. Mediators Inflamm 2015:167572

26. Motobu M, Amer S, Yamada M, Nakamura K, Saido-Sakanaka H, Asaoka A, Yamakawa M, Hirota Y (2004) Effects of antimicrobial peptides derived from the beetle Allomyrina dichotoma defensin on mouse peritoneal macrophages stimulated with lipopolysaccharide. J Vet Med Sci 66:319-322

27. Scott MG, Rosenberger CM, Gold MR, Finlay BB, Hancock RE (2000) An alpha-helical cationic peptide selectively modulates macrophage responses to lipopolysaccharide and directly alters macrophage gene expression. J Immunol 165:3358-3365

28. Scott MG, Davidson DJ, Gold MR, Bowdish D, Hancock RE (2002) The human antimicrobial peptide LL-37 is a multifunctional modulator of innate immune responses. J Immunol 169:3883-3891

29. Nagaoka I, Hirota S, Niyonsaba F, Hirata M, Adachi Y, Tamura H, Heumann D (2001) Cathelicidin family of antibacterial peptides CAP18 and CAP11 inhibit the expression of TNF-alpha by blocking the binding of LPS to CD14(+) cells. J Immunol 167:3329-3338

30. Wang Z, Wang X, Wang J (2018) Recent advances in antibacterial and antiendotoxic peptides or proteins from marine resource. Mar Drugs 16:57-74

31. Pearson G, Robinson F, Beers Gibson T, Xu BE, Karandikar M, Berman K, Cobb MH (2001) Mitogen-activated protein (MAP) kinase pathways: regulation and physiological functions. Endocr Rev 22:153-183

32. Raingeaud J, Whitmarsh AJ, Barrett T, Dérijard B, Davis RJ (1996) MKK3and MKK6-regulated gene expression is mediated by the p38 mitogen activated protein kinase signal transduction pathway. Mol Cell Biol $16: 1247-1255$
33. Ip YT, Davis RJ (1998) Signal transduction by the c-Jun N-terminal kinase (JNK)-from inflammation to development. Curr Opin Cell Biol 10:205-219

34. Bergmann M, Hart L, Lindsay M, Barnes PJ, Newton R (1998) IkBa degradation and nuclear factor-KB DNA binding are insufficient for interleukin-1 $\beta$ and tumor necrosis factor- $\alpha$-induced $k B$-dependent transcription Requirement for an additional activation pathway. J Biol Chem 273:6607-6610

35. Oh J, Rho HS, Yang Y, Yoon JY, Lee J, Hong YD, Kim HC, Choi SS, Kim TW, Shin SS, Cho JY (2013) Extracellular signal-regulated kinase is a direct target of the anti-inflammatory compound amentoflavone derived from Torreya nucifera. Mediators Inflamm 2013:1-11

36. Ray N, Kuwahara M, Takada Y, Maruyama K, Kawaguchi T, Tsubone H, Ishikawa H, Matsuo K (2006) c-Fos suppresses systemic inflammatory responses to endotoxin. Int Immunol 18:671-677

37. Korhonen R, Moilanen E (2014) Mitogen-activated protein kinase phosphatase 1 as an inflammatory factor and drug target. Basic Clin Pharmacol Toxicol 114:24-36

38. Emre Y, Hurtaud C, Nübel T, Criscuolo F, Ricquier D, Cassard-Doulcier AM (2007) Mitochondria contribute to LPS-induced MAPK activation via uncoupling protein UCP2 in macrophages. Biochem J 402:271-278

39. Woo CH, Lim JH, Kim JH (2004) Lipopolysaccharide induces matrix metalloproteinase-9 expression via a mitochondrial reactive oxygen speciesp38 kinase-activator protein-1 pathway in Raw 264.7 cells. J Immunol 173:6973-6980

40. Yang D, Elner SG, Bian ZM, Till GO, Petty HR, Elner VM (2007) Pro-inflammatory cytokines increase reactive oxygen species through mitochondria and NADPH oxidase in cultured RPE cells. Exp Eye Res 85:462-472

41. Wang Y, Yu X, Song H, Feng D, Jiang Y, Wu S, Geng J (2017) The STAT-ROS cycle extends IFN-induced cancer cell apoptosis. Int J Oncol 52:305-313

42. Quillet-Mary A, Jaffrézou J, Mansat V, Mansat V, Bordier C, Naval J, Laurent $\mathrm{G}$ (1997) Implication of mitochondrial hydrogen peroxide generation in ceramide-induced apoptosis. J Biol Chem 272:21388-21395

43. Hingorani R, Deng J, Elia J, Mclntyre C, Mittar D (2011) Detection of apoptosis using the BD Annexin V FITC assay on the BD FACSVerse ${ }^{\mathrm{TM}}$ system. https://www.bdbiosciences.com/documents/BD_FACSVerse_Apopt osis_Detection_AppNote.pdf. Accessed 30 Oct 2019

\section{Publisher's Note}

Springer Nature remains neutral with regard to jurisdictional claims in published maps and institutional affiliations.

\section{Submit your manuscript to a SpringerOpen ${ }^{\odot}$ journal and benefit from:}

- Convenient online submission

- Rigorous peer review

- Open access: articles freely available online

- High visibility within the field

- Retaining the copyright to your article

Submit your next manuscript at $\boldsymbol{\nabla}$ springeropen.com 